\title{
Ruminal protozoal contribution to the duodenal flow of fatty acids following feeding of steers on forages differing in chloroplast content
}

\author{
S. A. Huws ${ }^{1}$, M. R. F. Lee ${ }^{1}$, A. H. Kingston-Smith ${ }^{1}$, E. J. Kim ${ }^{2}$, M. B. Scott ${ }^{1}$, J. K. S. Tweed ${ }^{1}$ and \\ N. D. Scollan ${ }^{1 *}$ \\ ${ }^{1}$ Animal and Microbial Sciences, Institute of Biological, Environmental and Rural Sciences (IBERS), \\ Aberystwyth University, Gogerddan, Aberystwyth SY23 3EB, UK \\ ${ }^{2}$ Department of Animal Science, Kyungpook National University, Sangju 742-711, Republic of Korea
}

(Submitted 11 November 2011 - Final revision received 9 January 2012 - Accepted 17 January 2012 - First published online 1 March 2012)

\section{Abstract}

Ruminant products are criticised for their SFA content relative to PUFA, although $n-6: n-3$ PUFA is desirable for human health ( $<4$ ). Rumen protozoa are rich in unsaturated fatty acids due to engulfment of PUFA-rich chloroplasts. Increasing the chloroplast content of rumen protozoa offers a potentially novel approach to enhance PUFA flow to the duodenum and subsequent incorporation into meat and milk. We evaluated protozoal contribution to duodenal $n-3$ PUFA flow due to intracellular chloroplast content. A total of six Holstein $\times$ Friesian steers were fed, in a two-period changeover design, either straw:concentrate (S:C, 60:40; DM basis; S:C, low chloroplast) or fresh perennial ryegrass (PRG; high chloroplast). Following $12 \mathrm{~d}$ adaptation to diet, ruminal protozoal and whole duodenal samples were obtained. $\mathrm{N}$ and fatty acid content of whole duodenum and rumen protozoal samples were assessed and protozoal 18S rDNA quantitative PCR performed, enabling calculation of protozoal $\mathrm{N}$ flow. The ratio of individual fatty acids: $\mathrm{N}$ in rumen protozoal samples was calculated to obtain protozoal fatty acid flows. Based on total fatty acid flow, contribution (\%) of protozoa to individual fatty acid flows was calculated. Protozoal fatty acid data and microscopical observations revealed that protozoa were enriched with 18:3n-3 following PRG feeding, compared with the S:C diet, due to increased intracellular chloroplast content. However, duodenal protozoal $18 \mathrm{~S}$ rDNA concentration post PRG feeding was low, indicating rumen retention of the protozoa. Nutrition influences the $18: 3 n-3$ content of protozoa; the challenge is to increase protozoal flow to the small intestine, while maintaining sustainable rumen densities.

Key words: Protozoa: Chloroplasts: Fatty acids: Denaturing gradient gel electrophoresis: Quantitative PCR: Biohydrogenation: Rumen

Demand for ruminant products such as meat and milk is predicted to double by $2050^{(1)}$ and as such ensuring future meat and milk security in terms of availability, affordability and nutritional safety is at the forefront of agricultural research ${ }^{(2)}$. The WHO recommends that SFA intake should not exceed 0.35 of total fatty acid intake, the PUFA:SFA ratio should be about 0.4 and the $n-6: n-3$ PUFA ratio should be less than 4 in order to reduce the incidence of $\mathrm{CVD}^{(3)}$.

Ruminant products are often criticised for their SFA levels and PUFA:SFA ratio $(<0 \cdot 4)$, although they are noted for a beneficial $n$-6:n-3 PUFA ratio $(<4)^{(4)}$. The low PUFA:SFA ratio is due to the fact that rumen microbiota biohydrogenate dietary PUFA to SFA, producing conjugated diene and triene intermediates ${ }^{(5-7)}$. Some intermediates of biohydrogenation such as conjugated linoleic acid (CLA; cis-9, trans-11-CLA) and trans-11-18:1 have been implicated to be important in human health ${ }^{(8)}$.
Current evidence suggests that many as yet uncultured rumen bacteria belonging to the families: Prevotella, Lachnospiraceae incertae sedis, and unclassified Bacteroidales, Clostridiales and Ruminococcaceae have biohydrogenating capacity ${ }^{(9-12)}$. Thus, manipulation of rumen bacteria in order to improve the fatty acid quality of meat and milk is exceptionally difficult given the complexity and inability to currently culture the bacterial taxa involved in biohydrogenation.

Irrespective of their potential biohydrogenation capabilities, microbial cells that flow to the duodenum from the rumen are an important source of fatty acids for absorption by the animal. In terms of the rumen bacteria, previous reports show that they are proportionally high in odd-chain and branchedchain SFA ${ }^{(13-15)}$. There is some evidence that the rumen bacteria incorporate linoleic acid $(18: 2 n-6)^{(16)}$, but it is uncommon to find PUFA within the bacteria ${ }^{(17)}$. In contrast, rumen

Abbreviations: CLA, conjugated linoleic acid; DGGE, denaturing gradient gel electrophoresis; PRG, perennial ryegrass; S:C, straw:concentrate; WSC, watersoluble carbohydrate.

*Corresponding author: N. D. Scollan, fax +44 1970 823245, email ngs@aber.ac.uk 
protozoa are rich in beneficial PUFA, MUFA and CLA compared with rumen bacteria ${ }^{(18,19)}$. This is probably due to their ability to engulf chloroplasts, which contain most of total plant $18: 3 n-3$ within their thylakoid membranes ${ }^{(20-22)}$. Indeed, approximately $60 \%$ of the total chloroplast fatty acids are attributable to $18: 3 n-3^{(23,24)}$. Thus, enriching the chloroplast content of protozoa offers a novel strategy of ensuring increased PUFA flow to the duodenum. It is also possible that co-localisation of chloroplasts with engulfed bacteria within food vacuoles can result in intra-protozoal lipolysis and biohydrogenation of the intra-protozoal chloroplasts, providing that co-localised bacteria have lipolytic and biohydrogenating capacities. This may contribute to the previously reported high proportional representation of CLA in rumen protozoa ${ }^{(15,19)}$. Intra-protozoal chloroplast lipid metabolism may also aid direct uptake of the main chloroplast fatty acids ( $16: 0,18: 3 n-3$ and $18: 2 n-6)$ into the rumen protozoal membranes. As such, our aims in the present experiment were to evaluate the effects of increasing the chloroplast content of rumen protozoa on the duodenal flow of fatty acids shown to be beneficial for human health.

\section{Experimental methods}

\section{Animals, diets and experimental design}

The experiment was conducted under the authorities of the UK Animals (Scientific Procedures) Act (1986). A total of six Hereford $\times$ Friesian steers (Bos p. taurus) prepared with rumen and duodenal cannulae were employed and the experiment consisted of a two-period changeover design with two diets: fresh perennial ryegrass (PRG, Lolium perenne) cultivar AberElan, 3 weeks into a secondary re-growth (high chloroplast; PRG) and barley (Hordeum vulgare) straw:concentrate (S:C; 40:60 on a DM basis; Table 1; low chloroplast diet; S:C). Each diet was offered for a $12 \mathrm{~d}$ adaptation period before sample collection. Steers were allowed to eat ad libitum at 09.00 and 16.00 hours with refusals collected at 08.45 and 13.45 hours and DM intake determined. The building was well ventilated, with animals having free access to fresh water and minerals (Baby Red Rockies, Tithebarn Limited; composed of: $380 \mathrm{~g} / \mathrm{kg}$ $\mathrm{Na}, 5000 \mathrm{mg} / \mathrm{kg} \mathrm{Mg}, 1500 \mathrm{mg} / \mathrm{kg} \mathrm{Fe}, 300 \mathrm{mg} / \mathrm{kg} \mathrm{Cu}, 300 \mathrm{mg} / \mathrm{kg}$ $\mathrm{Zn}, 200 \mathrm{mg} / \mathrm{kg} \mathrm{Mn}, 150 \mathrm{mg} / \mathrm{kg} \mathrm{I}, 50 \mathrm{mg} / \mathrm{kg}$ Co and $10 \mathrm{mg} / \mathrm{kg} \mathrm{Se}$ ).

Table 1. Feed formulation for straw:concentrate mixture (40:60 on a DM basis)*

\begin{tabular}{lc}
\hline Ingredient & DM basis $(\mathrm{kg})$ \\
\hline Barley, rolled & 180 \\
Wheat, rolled & 80 \\
Molasses & 90 \\
Rapeseed meal & 225 \\
Straw, barley & 400 \\
Vitamins and minerals & 25 \\
Total & 1000 \\
ME $(\mathrm{MJ} / \mathrm{kg} \mathrm{DM})$ & 9.79 \\
Crude protein $(\mathrm{g} / \mathrm{kg} \mathrm{DM})$ & 151 \\
Ether extract $(\mathrm{g} / \mathrm{kg} \mathrm{DM})$ & 18.8 \\
\hline
\end{tabular}

ME, metabolisable energy.

${ }^{*}$ Concentrate was formulated and purchased from Wynnstay Group Plc.
Digesta flow at the duodenum was estimated using a dualphase marker technique with ytterbium acetate and Cr EDTA as the particulate and liquid phase markers, respectively ${ }^{(25)}$. Ytterbium acetate $(375 \mathrm{mg} \mathrm{Yb/d}$ ) and Cr EDTA (2401 mg Cr/d) were infused via separate lines intra-ruminally at a rate of $28 \mathrm{ml} / \mathrm{h}$ commencing on day 8 . On days 13 and $16,400 \mathrm{ml}$ of duodenal digesta were collected manually every $3 \mathrm{~h}$ over a $24 \mathrm{~h}$ period, bulked, stored at $4^{\circ} \mathrm{C}$ and processed as described by $\operatorname{Kim}$ et $a l .{ }^{(10)}$.

\section{Sample preparation and chemical analysis}

Feed was sampled once daily for straw and twice daily at feed times for PRG. Straw samples for the first $8 \mathrm{~d}$ and the latter $8 \mathrm{~d}$ were bulked, as chemical composition is unlikely to change across days, whereas due to the greater risk of chemical composition fluctuations between days ${ }^{(26)}$, daily PRG samples were kept separate. Samples were frozen, freeze-dried, ground and stored at $-20^{\circ} \mathrm{C}$ for later chemical analysis. Water-soluble carbohydrate (WSC) concentration of forages was determined spectrophotometrically using anthrone in sulphuric acid on a Technicon Autoanalyser (Technicon Corporation) ${ }^{(27)}$. Neutral-detergent fibre was determined as described by Van Soest et al. ${ }^{(28)}$, without the use of amylase or sodium sulphite for forages and using sodium sulphite and termamyl in place of amylase for concentrates, while using the Tecator Fibretec System (Tecator Limited). Acid-detergent fibre was analysed according to the method of Van Soest \& Wine ${ }^{(29)}$ using the Tecator Fibretec System (Tecator Limited). The fatty acid concentration of the diets was measured using a one-step extraction-transesterification procedure ${ }^{(30)}$. N concentration of diets and microbial fractions was analysed by combustion at $550^{\circ} \mathrm{C}$ using a LECO FP-428 analyser (LECO Corporation). Oil content was measured by diethyl ether extract ${ }^{(31)}$.

Collection of rumen samples took place $2 \mathrm{~h}$ after feeding on day 14 on both consecutive diets as described ${ }^{(22)}$. Bacterial contamination of fractionated protozoa was assessed using total eubacterial quantitative PCR as described in the following sections. Chlorophyll concentration was measured as an indicator of plant contamination extracellular to the protozoa alongside fluorescent microscopy ${ }^{(32)}$. Fatty acid composition of the microbial fractions and digesta was determined using a one-step extraction bimethylation approach as described by Kim et $a l{ }^{(10)}$.

\section{DNA extraction from rumen protozoal and whole duodenal samples}

Genomic DNA was extracted from rumen protozoal and whole duodenal samples (10 mg DM) using the BIO101 FastDNA ${ }^{\circledR}$ SPIN Kit for Soil (Qbiogene, Inc.) in conjunction with a FastPrep ${ }^{\circledR}$ cell disrupter instrument (Bio101, ThermoSavant, Qbiogene, Inc.) according to the manufacturer's instructions, with the exception that the samples were processed for $3 \times 30 \mathrm{~s}$ at speed $6 \cdot 0$ in the FastPrep instrument. DNA was quantified and the quality assured using the ND1000 nanodrop system (Labtech International Limited). 


\section{Total bacterial quantitative PCR}

In order to assess bacterial contamination in the protozoal fractions, quantitative PCR of bacterial $16 \mathrm{~S}$ rDNA was performed as described $^{(33,34)}$.

\section{Protozoal 185 rRNA-based PCR-denaturing gradient gel electrophoresis}

In order to validate that rumen and duodenal protozoal diversity was similar under both diets, PCR-denaturing gradient gel electrophoresis (DGGE) was used as described ${ }^{(22)}$.

\section{Total protozoal quantitative $P C R$}

Total protozoal 18S rDNA amplification was carried out on ruminal digesta samples in a final volume of $25 \mu \mathrm{l}$ containing $12.5 \mu \mathrm{l}$ SYBR $^{\circledR}$ Green JumpStart $^{\text {TM }}$ Taq ReadyMix ${ }^{\text {TM }}$ (Sigma-Aldrich), $250 \mathrm{~nm}$ each of $316 \mathrm{f} 5^{\prime}$-GCTTTCGWTGGTAGTGTATT- $3^{\prime}$ and 539r $5^{\prime}$-ACTTGCCCTCAAATCGT- $3^{\prime(22)}$, and $2 \mu \mathrm{l}$ of a $1: 50$ dilution of extracted genomic DNA. The thermal cycling programme was thirty cycles of $94^{\circ} \mathrm{C}$ for $30 \mathrm{~s}$ and $54^{\circ} \mathrm{C}$ for $30 \mathrm{~s}$, with an initial cycle of $94^{\circ} \mathrm{C}$ for $5 \mathrm{~min}$. After PCR, a dissociation curve (melting curve) was constructed in the range of $55-95^{\circ} \mathrm{C}$. All samples were run in triplicate and quantitative PCR were conducted on two separate occasions for the validation of results. A rumen protozoal DNA sample obtained from this study and determined to be low in plant and bacterial contamination was used as a protozoal standard.

\section{Microscopy}

Total protozoal densities as well as proportions of holotrich and entodinomorphid protozoa were assessed using a Sedgewick rafter counting chamber and an Olympus $\mathrm{BH}-2$ microscope (Olympus UK Limited). Proportional representation of the main entodinomorphid protozoa was also recorded. Total protozoa, as well as proportions of holotrichs and entodinomorphid protozoa containing intracellular auto-fluorescing chloroplasts, were assessed using an Olympus BH-2 fluorescent microscope by scanning 100 protozoa in each of the samples. Percentage of total protozoa as well as proportions of holotrichs and entodinomorphid protozoa saturated ( $>10 /$ cell) with intracellular chloroplast was also recorded.

\section{Calculations and statistical analysis}

Digesta flows were estimated after mathematical reconstitution of true digesta as described by Faichney ${ }^{(25)}$. The N:total DNA ratios and the $\mathrm{N}$ :individual fatty acid ratios were recorded for rumen protozoal samples, and the duodenal flows of protozoal DNA, $\mathrm{N}$ and individual fatty acids were calculated as described $^{(35-38)}$. Data for protozoal density, chloroplast, N, DNA, fatty acid content, intakes and flows of DM, fatty acids following feeding with either S:C or PRG were subjected to ANOVA using GenStat 13th Edition (VSNi) ${ }^{(39)}$.

\section{Results}

\section{Chemical composition of the experimental diets}

The S:C diet was lower in WSC and oil, but was similar in N, neutral- detergent fibre and acid-detergent fibre concentration compared with the fresh PRG diet (Table 2). Fatty acid composition of the S:C diet was: $7 \cdot 9 \% 18: 3 n-3,14.4 \% 16: 0$ and $35.5 \%$ $18: 2 n-6$. The DM, total N, WSC, acid-detergent fibre and neutral-detergent fibre of the PRG were comparable to that stated by Lee et $a l .{ }^{(31)}$ and Huws et al. ${ }^{(22)}$ for the same PRG cultivar. Fatty acid composition of the PRG was $63 \cdot 3 \% 18: 3 n-3,15 \cdot 1 \%$ $16: 0$ and $14.5 \% 18: 2 n-6$.

\section{Rumen and duodenal protozoal diversity}

DGGE comparisons of rumen $v$. duodenal protozoal diversity on each diet separately showed that rumen and duodenal protozoal diversity was similar following S:C and PRG feeding (Fig. 1). Fig. 1 illustrates the data for steer no. 1 post-PRG and $\mathrm{S}$ :C feeding only but these data are representative of similarities found within the other steers.

\section{Bacterial and plant contamination levels of rumen protozoal samples}

Bacterial 16S rDNA:protozoal 18S rDNA density in the rumen protozoal samples was on average 0.18:1. Microscopy and extra-protozoal chlorophyll quantification revealed that plant contamination was comparatively minimal within these samples (average protozoal extracellular chlorophyll quantity was $6.2 \mathrm{mg} / \mathrm{g}$ protozoal DM following S:C feeding compared with a $30.8 \mathrm{mg} / \mathrm{g}$ following PRG feeding, while chlorophyll intake was $48.2 \mathrm{~g} / \mathrm{d}$ following S:C feeding and $290 \cdot 1 \mathrm{~g} / \mathrm{d}$ following PRG feeding, on a DM basis).

Table 2. Chemical composition ( $\mathrm{g} / \mathrm{kg} \mathrm{DM}$, unless stated) and fatty acid profile of the experimental diets

(Mean values, $n 4$ for both diets)

\begin{tabular}{lcc}
\hline & $\begin{array}{c}\text { S:C } \\
\text { Mean }\end{array}$ & $\begin{array}{c}\text { PRG } \\
\text { Mean }\end{array}$ \\
\hline DM $(\mathrm{g} / \mathrm{kg})$ & 948 & 932 \\
Total N & $21 \cdot 7$ & $22 \cdot 0$ \\
Water-soluble carbohydrate & $67 \cdot 0$ & 158 \\
Neutral-detergent fibre & 470 & 476 \\
Acid-detergent fibre & 277 & 273 \\
Oil & $12 \cdot 6$ & $19 \cdot 7$ \\
Fatty acid composition & & \\
$12: 0$ & $0 \cdot 03$ & $0 \cdot 03$ \\
$14: 0$ & $0 \cdot 12$ & $0 \cdot 08$ \\
$16: 0$ & $3 \cdot 12$ & $3 \cdot 86$ \\
$16: 1 n-7$ & $0 \cdot 16$ & $0 \cdot 04$ \\
$18: 0$ & $0 \cdot 37$ & $0 \cdot 29$ \\
$18: 1 n-9$ & $6 \cdot 13$ & 0.45 \\
$18: 2 n-6$ & $7 \cdot 66$ & 3.71 \\
$18: 3 n-3$ & $1 \cdot 71$ & $16 \cdot 2$ \\
\hline
\end{tabular}

$\mathrm{S}: \mathrm{C}$, straw:concentrate; PRG, perennial ryegrass. 


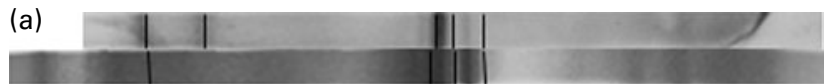

(b)

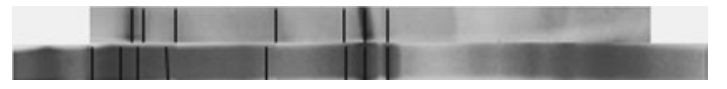

Steer 1 duodenum

Steer 1 rumen

Steer 1 duodenum

Steer 1 rumen

Fig. 1. Denaturing gradient gel electrophoresis profiles comparing rumen and duodenal protozoal $18 \mathrm{~S}$ rDNA diversity for steer 1 following (a) straw:concentrate (60:40; DM basis) and (b) fresh perennial ryegrass feeding of steers.

\section{Daily nutrient intake and duodenal flows}

DM intake averaged 8.80 and $9.42 \mathrm{~kg} / \mathrm{d}$ following feeding of $\mathrm{S}: \mathrm{C}$ and PRG, respectively (Table 3). DM, N, neutral-detergent fibre and acid-detergent fibre intake did not differ between diets, whereas WSC intake was higher when steers were offered PRG compared with when offered S:C (Table 3). Intake of 16:0 and 18:3n-3 was greater following PRG feeding compared with S:C feeding (Table 3). Conversely, 16:1n-7, 18:1n-9 and 18:2n-6 intake were greater following feeding of S:C compared with PRG (Table 3). Duodenal flow of DM and organic matter were comparable post-feeding on both experimental diets (Table 3). Total $\mathrm{N}$ flowing to the duodenum was nonetheless higher post-feeding on PRG compared with the S:C diet, although the difference in total $\mathrm{N}$ flow did not reach significance at $P<0.05$ (Table 3). Protozoal $\mathrm{N}$ flowing to the duodenum was nonetheless significantly higher postfeeding on S:C compared with the PRG diet (Table 3).

\section{Ruminal protozoal chloroplast, fatty acid, DNA and nitrogen content}

Protozoal density post-feeding of PRG was lower compared with post-feeding with S:C (Table 4). All microscopically visualised protozoa were entodinomorpids, with undetectable

Table 3. Daily intakes and duodenal flows of DM, organic matter (OM) and nitrogen in steers, straw:concentrate $(\mathrm{S}: \mathrm{C})$ or fresh perennial ryegrass (PRG; $g / d$, unless stated)

(Mean values and standard errors of the difference)

\begin{tabular}{lcccc}
\hline & $\begin{array}{c}\text { S:C } \\
\text { Mean }\end{array}$ & $\begin{array}{c}\text { PRG } \\
\text { Mean }\end{array}$ & SED & $P$ \\
\hline Intake & & & & \\
DM (kg/d) & 8.80 & 9.42 & 0.54 & $\mathrm{NS}^{*}$ \\
Total N & 191 & 207 & 11.8 & $\mathrm{NS}^{*}$ \\
Water-soluble carbohydrate & 607 & 1488 & 52.2 & $<0.001$ \\
Neutral-detergent fibre & 4136 & 4481 & 255 & $\mathrm{NS}^{*}$ \\
Acid-detergent fibre & 2439 & 2571 & 149 & $\mathrm{NS}^{*}$ \\
Fatty acid intake & & & & \\
$12: 0$ & 0.28 & 0.26 & 0.02 & $\mathrm{NS}^{*}$ \\
$14: 0$ & 0.75 & 1.10 & 0.10 & 0.007 \\
$16: 0$ & 27.0 & 36.0 & 1.80 & 0.008 \\
$16: 1 n-7$ & 1.4 & 0.4 & 0.07 & $<0.001$ \\
$18: 0$ & 3.26 & 2.73 & 0.20 & 0.05 \\
$18: 1 n-9$ & 54.0 & 4.2 & 2.59 & $<0.001$ \\
$18: 2 n-6$ & 50.7 & 35.0 & 3.21 & 0.008 \\
$18: 3 n-3$ & 15.1 & 153 & 3.71 & $<0.001$ \\
Duodenal flow & & & & \\
DM (kg/d) & 12.2 & 12.1 & 0.74 & $\mathrm{NS}^{*}$ \\
OM (kg/d) & 11.8 & 11.5 & 0.63 & $\mathrm{NS}^{*}$ \\
Total N & 125 & 169 & 31.5 & $\mathrm{NS}^{*}$ \\
Protozoal N & 34.4 & 0.70 & 9.84 & 0.027 \\
\hline
\end{tabular}

* Values were not significantly different $(P>0.10)$. densities of holotrichs present on both experimental diets (Table 4). The entodinomorphid protozoal genera present post-feeding of both diets was similar (Table 4). Although post-PRG feeding the percentage of protozoa containing intracellular chloroplasts was not different to the percentage of protozoa containing intracellular chloroplasts post-S:C feeding, $5 \%$ of the population (mainly Polyplastron spp. and Diplodinium spp.) were saturated $(>10)$ with intracellular chloroplasts while none of the visualised protozoa had $>10$ intracellular chloroplasts post-S:C feeding (Table 4). This increase in the number of intracellular chloroplasts post-PRG feeding coincided with an increased protozoal concentration of 18:3n-3, expressed on a $\mathrm{N}$ basis (Table 4). Concentrations of the biohydrogenation intermediate trans-11-18:1 was also higher post-PRG feeding compared with levels post-S:C feeding (Table 4). Protozoal concentrations of $18: 2 n-6$, cis-9, trans-11CLA and trans-10, cis-12-CLA were conversely higher post-S:C feeding as opposed to PRG feeding (Table 4).

\section{Contribution of protozoa to duodenal fatty acid flow}

Total duodenal flow of 14:0, 15:0, cis-9, trans-11-CLA and $18: 2 n-6$ was lower post-PRG compared with S:C feeding (Table 5). Conversely, duodenal flow of $16: 0,17: 0,18: 0$, trans-11$18: 1,18: 3 n-3$ and trans-10, cis-12-CLA was greater post-PRG compared with S:C feeding (Table 5). Following S:C feeding of steers, protozoal flow to the duodenum accounted for $80 \%$ of total cis-9, trans-11, 26.2\% trans-11-18:1, 21.5\% 16:0, 12.9\% $18: 2 n-6$ and $8 \cdot 4 \% 18: 3 n-3$ (Table 5). Nonetheless, contribution of protozoa to the flow of all reported fatty acids post-PRG feeding was low due to the low duodenal ciliate 18S rDNA concentration within duodenal samples (protozoal 18S rDNA concentration in duodenum following S:C feeding was $11.7 \mu \mathrm{g} / \mathrm{mg}$, compared with $0.3 \mu \mathrm{g} / \mathrm{mg}$ following PRG feeding; although rumen protozoal 18S rDNA concentration following S:C feeding was $117 \cdot 2 \mu \mathrm{g} / \mathrm{mg}$, compared with $87 \cdot 8 \mu \mathrm{g} / \mathrm{mg}$ following PRG feeding).

\section{Discussion}

In the present study, we used developed methods to estimate the contribution that protozoa make to duodenal fatty acid flow as a consequence of their intracellular chloroplast content ${ }^{(35-38)}$. These methods are based on having sufficient similarity in rumen and duodenal protozoal $18 \mathrm{~S}$ rDNA diversity, such that rumen samples can then be used as standards to calculate protozoal 18S rDNA:N, N:protozoal individual fatty acid, allowing duodenal protozoal $\mathrm{N}$ and individual fatty acid duodenal flow to be calculated. This subsequently allows us to calculate the protozoal contribution to total fatty acid duodenal flow. 
Table 4. Rumen protozoal density and protozoal chloroplast, nitrogen, DNA and fatty acid content following feeding with either straw:concentrate $(\mathrm{S}: \mathrm{C})$ or fresh perennial ryegrass $(\mathrm{PRG})$

(Mean values and standard errors of the difference, $n 4$ )

\begin{tabular}{|c|c|c|c|c|}
\hline & \multicolumn{4}{|c|}{ Diet } \\
\hline & $\begin{array}{c}\text { S:C } \\
\text { Mean }\end{array}$ & $\begin{array}{l}\text { PRG } \\
\text { Mean }\end{array}$ & SED & $P$ \\
\hline \multicolumn{5}{|l|}{ Protozoal density $\left(10^{3}\right.$ cells $\left./ \mathrm{ml}\right)$} \\
\hline Total & 903 & 121 & $0.18 \dagger$ & $<0.01$ \\
\hline Holotrich & ND & ND & NA & NA \\
\hline Entodiniomorphid & 903 & 121 & $0.18 \dagger$ & $<0.01$ \\
\hline Entodinium spp. (\%) & $86 \cdot 0$ & 79.4 & & \\
\hline Diplodinium spp. (\%) & $10 \cdot 8$ & $14 \cdot 2$ & & \\
\hline Eudiplodinium spp. (\%) & 0.0 & $0 \cdot 2$ & & \\
\hline Polyplastron spp. (\%) & $2 \cdot 8$ & 4.8 & & \\
\hline Ermplastron spp. (\%) & 0.0 & $0 \cdot 2$ & & \\
\hline Metadinium spp. (\%) & 0.0 & 1.8 & & \\
\hline \multicolumn{5}{|c|}{ Protozoa containing intracellular chloroplasts (\%) } \\
\hline Total & $26 \cdot 0$ & 27.5 & 4.43 & $\mathrm{NS}^{*}$ \\
\hline Holotrich & ND & ND & ND & NA \\
\hline Entodiniomorphid & $26 \cdot 0$ & $27 \cdot 5$ & 4.43 & $\mathrm{NS}^{*}$ \\
\hline \multicolumn{5}{|c|}{ Protozoa saturated with intracellular chloroplasts (>10/cell) $(\%)$} \\
\hline Total & 0.00 & $5 \cdot 00$ & $1 \cdot 60$ & $<0.05$ \\
\hline Holotrich & ND & ND & NA & NA \\
\hline Entodiniomorphid & 0.00 & $5 \cdot 00$ & $1 \cdot 60$ & $<0.05$ \\
\hline \multicolumn{5}{|l|}{ Rumen protozoal standard data } \\
\hline Protozoal $\mathrm{N}$ content $(\mathrm{mg} / \mathrm{g})$ & $44 \cdot 0$ & $40 \cdot 8$ & $9 \cdot 57$ & $\mathrm{NS}^{*}$ \\
\hline DNA:N $(\mu \mathrm{g} / \mathrm{mg})$ & 3.37 & $6 \cdot 29$ & 1.42 & $\mathrm{NS}^{*}$ \\
\hline \multicolumn{5}{|c|}{ Protozoal fatty acid content $(\mu \mathrm{g} / \mathrm{mg} \mathrm{N})$} \\
\hline $14: 0$ & $7 \cdot 78$ & $8 \cdot 65$ & 1.50 & $\mathrm{NS}^{*}$ \\
\hline $15: 0$ & 8.90 & 12.4 & $2 \cdot 85$ & $\mathrm{NS}^{*}$ \\
\hline $16: 0$ & 132 & 101 & 38.4 & $\mathrm{NS}^{*}$ \\
\hline $17: 0$ & $3 \cdot 24$ & 4.03 & 3.98 & 0.012 \\
\hline $18: 0$ & 201 & 288 & 167 & $\mathrm{NS}^{*}$ \\
\hline trans-11-18: 1 & $36 \cdot 6$ & $87 \cdot 6$ & 43.0 & $<0.001$ \\
\hline $18: 2 n-6$ & 33.5 & $8 \cdot 80$ & 3.54 & $<0.001$ \\
\hline $18: 3 n-3$ & $3 \cdot 30$ & $18 \cdot 1$ & $5 \cdot 14$ & $<0.001$ \\
\hline cis-9, trans-11-CLA & $3 \cdot 82$ & 0.67 & 0.84 & $<0.001$ \\
\hline trans-10, cis-12-CLA & 0.17 & 0.00 & 0.07 & $<0.001$ \\
\hline Total & 608 & 653 & 287 & $\mathrm{NS}^{*}$ \\
\hline
\end{tabular}

ND, not detected; NA, not applicable; CLA, conjugated linoleic acid.

${ }^{*}$ Mean values were not significantly different $(P>0 \cdot 10)$

†SED values are in log scale.

Table 5. Total fatty acid and protozoal-related fatty acid duodenal flow in steers fed straw:concentrate (S:C) or fresh perennial ryegrass (PRG) (Mean values and standard errors of the difference)

\begin{tabular}{|c|c|c|c|c|c|c|c|c|c|c|}
\hline & \multicolumn{3}{|c|}{ Duodenal flow $(\mathrm{g} / \mathrm{d})$} & \multirow[b]{2}{*}{$P$} & \multicolumn{3}{|c|}{ Protozoal flow (g/d) } & \multirow[b]{2}{*}{$P$} & \multicolumn{2}{|c|}{ Contribution* } \\
\hline & $\begin{array}{c}S: C \\
\text { Mean }\end{array}$ & $\begin{array}{l}\text { PRG } \\
\text { Mean }\end{array}$ & SED & & $\begin{array}{c}\mathrm{S}: \mathrm{C} \\
\text { Mean }\end{array}$ & $\begin{array}{l}\text { PRG } \\
\text { Mean }\end{array}$ & SED & & $\mathrm{S}: \mathrm{C}$ & PRG \\
\hline $14: 0$ & $2 \cdot 29$ & 1.72 & 0.21 & 0.024 & 0.26 & 0.00 & 0.07 & $<0.001$ & 11.4 & 0.33 \\
\hline $15: 0$ & 1.44 & 1.27 & 0.15 & $<0.001$ & 0.32 & 0.00 & 0.19 & $<0.001$ & $52 \cdot 8$ & $3 \cdot 15$ \\
\hline $16: 0$ & 24.9 & $25 \cdot 5$ & 1.30 & 0.008 & $5 \cdot 36$ & 0.16 & 3.91 & 0.114 & 21.5 & 0.63 \\
\hline $17: 0$ & 1.32 & 1.56 & $0 \cdot 15$ & $<0.001$ & $0 \cdot 13$ & 0.00 & 0.09 & $<0.001$ & $9 \cdot 85$ & 0.23 \\
\hline $18: 0$ & $88 \cdot 6$ & 102 & $9 \cdot 77$ & 0.006 & $8 \cdot 76$ & 0.26 & 7.66 & 0.193 & $9 \cdot 89$ & 0.25 \\
\hline trans-11-18: 1 & $5 \cdot 20$ & $24 \cdot 0$ & $2 \cdot 34$ & $<0.001$ & 1.36 & 0.07 & 0.90 & $<0.001$ & $26 \cdot 2$ & 0.29 \\
\hline $18: 2 n-6$ & $10 \cdot 2$ & $2 \cdot 21$ & 0.33 & $<0.001$ & 1.32 & 0.02 & 0.88 & $<0.001$ & $12 \cdot 9$ & 0.09 \\
\hline $18: 3 n-3$ & 1.66 & 3.06 & 0.23 & $<0.001$ & 0.14 & 0.01 & $0 \cdot 11$ & $<0.001$ & 8.43 & 0.33 \\
\hline cis-9, trans-11-CLA & $0 \cdot 10$ & 0.08 & 0.02 & $<0.001$ & 0.08 & 0.00 & 0.134 & $<0.001$ & $80 \cdot 0$ & $2 \cdot 00$ \\
\hline trans-10, cis-12-CLA & 0.00 & 0.06 & 0.01 & $<0.001$ & 0.00 & 0.00 & 0.00 & $<0.001$ & $50 \cdot 0$ & 0.00 \\
\hline Total fatty acids & 173 & 196 & $15 \cdot 7$ & 0.002 & $23 \cdot 8$ & 0.46 & $16 \cdot 4$ & 0.096 & $13 \cdot 8$ & 0.23 \\
\hline
\end{tabular}

CLA, conjugated linoleic acid.

${ }^{\star}$ Contribution of protozoa to fatty acid duodenal flow (protozoal fatty acid flow/total fatty acid flow $\times 100 \%$ ). 
Rumen protozoal samples were relatively low in bacterial contamination (18\% of total DNA was bacterial in origin), and values were comparable to those reported previously ${ }^{(22,38,40)}$. Microscopical visualisation of samples coupled with extra-protozoal chlorophyll quantification also confirmed that samples were low in plant contamination. Average $\mathrm{N}$ concentration of the protozoa was also comparable with previous data ${ }^{(22,41,42)}$. Fatty acid content of the rumen protozoa, on a $\mathrm{N}$ basis, was similar to those reported by Yáñez-Ruiz et al ${ }^{(38)}$; however, both $18: 2 n-6$ and $18: 3 n-3$ protozoal content were lower, on a $\mathrm{N}$ basis, following feeding on both diets compared with the Yáñez-Ruiz et al. ${ }^{(38)}$ data. The reasoning for this discrepancy is unclear. When expressed as $\mathrm{mg} / \mathrm{g}$, our data are similar to the data we obtained in the previous study with respect to all intra-protozoal fatty acid concentrations reported. Specifically, protozoal $18: 3 n-3$ content was similar between this study and our previous work (S:C average $-0.57 \mathrm{mg} / \mathrm{g}$ $\mathrm{DM}, \mathrm{PRG}-0.78 \mathrm{mg} / \mathrm{g} \mathrm{DM}$ in this study compared with average values reported in Huws et al. ${ }^{(22)}$ : hay/concentrate $-0.46 \mathrm{mg} / \mathrm{g}$ DM, fresh PRG $-1.36 \mathrm{mg} / \mathrm{g} \mathrm{DM})$. The slightly lower protozoal $18: 3 n-3$ content post-PRG feeding may be due to the fact that the steers used in this study contained type A protozoa whereas the steers contained type B protozoa in our previous study ${ }^{(22)}$. We previously noted that Epidinium spp. were commonly saturated with intracellular chloroplast post-PRG feeding, and were consequentially the most concentrated in $18: 3 n$-3. In this study, type A protozoal populations do not harbour Epidinium spp., therefore potentially explaining the slightly lower 18:3n-3 content post-PRG, although it should be noted that some Polyplastron and Diplodinium spp. within this study did contain $>10$ intracellular chloroplasts. The fatty acid contents of protozoa post-S:C feeding of steers were also similar to those previously reported when a conserved forage was fed ${ }^{(15,18,19)}$. Irrespective of this, post-fresh PRG feeding rumen protozoa were enriched in: $17: 0$, trans-11-18:1, 18:3n-3 and lower in 18:2n-6, cis-9, trans-11-and trans-10, cis-12-CLA compared with concentrations post-S: $\mathrm{C}$ feeding. These differences in protozoal fatty acid content are similar to those reported in our previous study comparing hay/concentrate or fresh $\mathrm{PRG}^{(22)}$. In this study, 18:3n-3 content of protozoa post-PRG feeding was $5.5 \times$ higher than the levels post-S:C feeding. The difference in $18: 3 n-3$ content of the protozoa was not a product of having differential numbers of genera known to engulf chloroplasts more effectively. Polyplastron spp. made up $2 \cdot 8$ and $4 \cdot 8 \%$ of the total protozoal population while Diplodinium spp. made up 10.8 and $14.2 \%$ of the total protozoal population postfeeding of S:C and PRG, respectively. Taking into account the total protozoal numbers, Polyplastron spp. were present at $97.5 \times 10^{3}$ and $17 \cdot 1 \times 10^{3}$ cells $/ \mathrm{ml}$ following S:C and PRGfeeding, respectively. Likewise, taking into account the total protozoal numbers, Diplodinium spp. were present at $25.3 \times 10^{3}$ and $5.08 \times 10^{3}$ cells $/ \mathrm{ml}$ following S:C and PRG feeding, respectively. Post-PRG feeding, $5 \%$ of protozoa had $>10$ chloroplasts/cell but no protozoa had reached these saturation levels post-S:C feeding. Thus, this $18: 3 n-3$ differential is likely to be due to differences in chloroplast concentration between the diets, intake and subsequent protozoal content. If food vacuoles containing chloroplasts also contained lipolytic bacteria, then this $18: 3 n-3$ differential could also be due to direct uptake into membranes. Intake of $18: 3 n-3$ by the steers was $10 \times$ fold higher following PRG feeding compared with S:C feeding, associated with the higher chloroplast content of PRG. Studies have shown that a high proportion $(>50 \%)$ of plant cells are intact post-mastication ${ }^{(43)}$. Thus, mastication may have caused some lysis and release of $18: 3 n-3$ from the chloroplast thylakoid membranes to the extracellular mileu, thereby reducing the available chloroplasts for protozoal ingestion and thus potentially explaining the slight difference in 18:3n-3 intake. Bioavailability of some chloroplasts may also be problematic, which may also mean that not all ingested chloroplasts can be engulfed by the rumen protozoa. It may also be the case that protozoal chloroplast intake was maximum irrespective of the availability of chloroplast for protozoal engulfment.

CLA concentration of ruminal protozoa fractionated post-PRG feeding was negligible compared with concentrations following S:C feeding. Conversely, concentrations of trans-11-18: 1 were higher in ruminal protozoa fractionated from steers fed PRG compared with those from S:C-fed steers. Recent data suggest that the protozoa do not play a role in the saturation of PUFA or the desaturation of trans-11-18: 1 to CLA ${ }^{(19)}$. As such, the reason for the intracellular CLA and trans-11-18: 1 concentrations within these eukaryotes has been hypothesised to be due to preferential incorporation of these fatty acids into their cellular membranes, with their formation related to differences between diets ${ }^{(19)}$. It could also be the case that lipolytic and biohydrogenating bacteria may be co-localised with the intra-protozoal chloroplasts causing intra-protozoal formation of trans-11-18: 1 .

Using established methods ${ }^{(35-38)}$, we have shown that post$\mathrm{S}: \mathrm{C}$ feeding of steers, protozoal $\mathrm{N}$ flowing to the duodenum is approximately $34.4 \mathrm{~g} / \mathrm{d}$. This value is higher than the estimates of $13-18 \mathrm{~g} / \mathrm{d}$ obtained by some researchers ${ }^{(38,44-46)}$, but close to the $38.1 \mathrm{~g} / \mathrm{d}$ estimated by Sylvester et al. ${ }^{(36)}$ in the post-feeding of Holstein cows on a high-fibre diet. This difference is probably due to the differing diets between the studies. A high-concentrate diet is known to increase the protozoal $\mathrm{N}$ content $^{(47)}$, and thus is likely to lead to higher protozoal $\mathrm{N}$ duodenal flow. Protozoal $\mathrm{N}$ flowing to the duodenum postPRG feeding of steers was substantially less at approximately $0.70 \mathrm{~g} / \mathrm{d}$. This value is closer to values of approximately $2.0 \mathrm{~g} /$ d obtained by Harrison et al. ${ }^{(47)}$ using other pre-molecular technologies and more recently those obtained by Belanche et al. ${ }^{(48)}$ using molecular techniques as described within this study ( $0 \cdot 15$ and $0.5 \mathrm{~g} / \mathrm{d}$ protozoal $\mathrm{N}$ flow following feeding of sheep alfalfa (Medicago sativa) hay and a mixed sward hay, respectively).

Post-S:C feeding, the contribution of protozoa to fatty acids flowing to the duodenum was broadly similar to the results of Yáñez-Ruiz et al. ${ }^{(38)}$. Trans-11-18: 1 is important due to its conversion to cis-9, trans-11-18:2 in bovine mammary glands ${ }^{(49)}$. Thus, this study along with the previous study ${ }^{(38)}$ highlights the potentially important contribution that protozoa make to the duodenal flow of key beneficial fatty acids, which are beneficial to human health, in animals on concentrate-based diets. Nonetheless, we were interested in testing the hypothesis that an improvement in $18: 3 n-3$ flow to the duodenum could be made by increasing the chloroplast content of the diet, and thus the chloroplast content of the protozoa. Contribution of 
ruminal protozoa to the flow of all fatty acids was substantially lower post-PRG feeding compared with S:C feeding. Focusing on the contribution of protozoa post-PRG feeding to $18: 3 n-3$ duodenal flow, this was $0.33 \%$ compared with $8.43 \%$ post-S:C feeding. This was due to the much lower protozoal $18 \mathrm{~S}$ rDNA concentrations present within the duodenal samples post-PRG feeding of steers. This suggests that fresh grass feeding results in substantial ruminal retention of protozoa. DGGE profiles suggest that the retention was not selective, as the rumen and duodenal profiles were similar. There is evidence to show that some protozoa preferentially attach to plant material containing a high soluble sugar content ${ }^{(50)}$. Thus, the reason for this retention following fresh grass feeding is possibly due to the high WSC content of the PRG which provides the rumen protozoa with a favourable ecosystem potentially causing them to evade flow through to the abomasum; for example, associated with large food particles or inhabiting the bottom of the raft.

In conclusion, PRG feeding increases the intracellular chloroplast and coincidently the $18: 3 n-3$ content of protozoa. This may be due directly to engulfment of the 18:3n-3-rich chloroplasts and/or due to intra-protozoal lipid metabolism and subsequent uptake of PUFA into the protozoa cell membranes. The fresh grass diet did, however, cause ruminal protozoal retention and therefore this enhanced protozoal $n$ - 3 PUFA content did not result in an increased flow to the duodenum. The challenge ahead is to capitalise on the benefits offered by chloroplast uptake by rumen protozoa in terms of capture of PUFA, while ensuring adequate protozoa flow and maintenance of rumen protozoal density.

\section{Acknowledgements}

The authors acknowledge funding from the Biotechnology and Biological Sciences Research Council (UK), Department of Environment Food and Rural Affairs, English Beef and Lamb Executive, Hybu Cig Cymru, Quality Meat Scotland and European Union Prosafebeef (FOOD-CT-2006-36241). The authors state that there are no conflicts of interest. The present experiment was instigated and designed by S. A. H. and N. D. S. Sample retrieval was accomplished by S. A. H., M. R. F. L., E. J. K. and M. B. S., while sample analysis was conducted by S. A. H., A. H. K.-S., M. B. S. and J. K. S. T. The authors are grateful to Animal and Microbial Science technical staff for their help with animal care.

\section{References}

1. Food and Agriculture Organization of the United Nations (2009) FAOSTAT. http://faostat.fao.org/.

2. The Government Office for Science, London (2011) Foresight. The Future Of Food and Farming: Challenges and Choices for Global Sustainability. Final Project Report. http://www.bis.gov.uk/assets/bispartners/foresight/docs/ food-and-farming/11-546-future-of-food-and-farming-report.

3. World Health Organization (2003) Diet, Nutrition and Prevention of Chronic Diseases. WHO Technical Report Series no. 916. Geneva: WHO.

4. Scollan ND, Hocquette J-F, Nuernberg K, et al. (2006) Innovations in beef production systems that enhance the nutritional and health value of beef lipids and their relationship with meat quality. Meat Sci $\mathbf{7 4}, 17-33$.

5. Węsowska I, Maia MRG, Niedźwiedzka KM, et al. (2006) Influence of fish oil on ruminal biohydrogenation of C18 unsaturated fatty acids. Br J Nutr 95, 1199-1211.

6. Jenkins TC, Wallace RJ, Moate PJ, et al. (2008) Board-invited review: recent advances in biohydrogenation of unsaturated fatty acids within the rumen microbial ecosystem. J Anim Sci 86, 397-412.

7. Lourenço M, Ramos-Morales E \& Wallace RJ (2010) The role of microbes in rumen lipolysis and biohydrogenation and their manipulation. Animal 4, 1008-1023.

8. Lock AL \& Bauman DE (2004) Modifying milk fat composition of dairy cows to enhance fatty acids beneficial to human health. Lipids 39, 1197-1206.

9. Boeckaert C, Vlaeminck B, Fievez V, et al. (2008) Accumulation of trans C18:1 fatty acids in the rumen after dietary algal supplementation is associated with changes in the Butyrivibrio population. Appl Environ Microbiol $\mathbf{7 4}$, 6923-6930.

10. Kim EJ, Huws SA, Lee MRF, et al. (2008) Fish oil increases the duodenal flow of long chain polyunsaturated fatty acids and trans-11 18:1 and decreases 18:0 in steers via changes in the rumen bacterial community. J Nutr 138, 889-896.

11. Belenguer A, Toral PG, Fructos P, et al. (2010) Changes in the rumen bacterial community in response to sunflower oil and fish oil supplements in the diet of dairy sheep. J Dairy Sci 93, 3275-3286.

12. Huws SA, Kim EJ, Lee MRF, et al. (2011) As yet uncultured bacteria phylogenetically classified as Prevotella, Lachnospiraceae incertae sedis, and unclassified Bacteroidales, Clostridiales and Ruminococcaceae may play a predominant role in ruminal biohydrogenation. Environ Microbiol 13, 1500-1512.

13. Williams PP \& Dinusson WE (1973) Amino acid and fatty acid composition of bovine ruminal bacteria and protozoa. J Anim Sci 36, 151-155.

14. Kim EJ, Sanderson R, Dhanoa MS, et al. (2005) Fatty acid profiles associated with microbial colonization of freshly ingested grass and rumen biohydrogenation. J Dairy Sci $\mathbf{8 8}, 3220-3230$.

15. Or-Rashid MM, Odongo NE \& McBride BW (2007) Fatty acid composition of ruminal bacteria and protozoa, with emphasis on conjugated linoleic acid, vaccenic acid, and odd-chain and branched-chain fatty acids. J Anim Sci 85, 1228-1234.

16. Hawke JC (1971) The incorporation of long-chain fatty acids into lipids by rumen bacteria and the effect on biohydrogenation. Biochim Biophys Acta 248, 201-212.

17. Goldfine H (1982) Lipids of prokaryotes: structure and distribution. In Current Topics in Membranes and Transport, pp. 1-43 [F Bronner and A Kleinzeller, editors]. New York/ London: Academic Press.

18. Emmanuel B (1974) On the origin of rumen protozoan fatty acids. Biochim Biophys Acta 337, 404-413.

19. Devillard E, McIntosh FM, Newbold, et al. (2006) Rumen ciliate protozoa contain high concentrations of conjugated linoleic acids and vaccenic acid, yet do not hydrogenate linoleic acid or desaturate stearic acid. BrJ Nutr 96, 697-704.

20. Hall FJ, West J \& Coleman GS (1974) Fine ultrastructural studies on the digestion of chloroplasts in the rumen ciliate Entodinium caudatum. Tissue Cell 6, 243-253.

21. Stern MD, Hoover WH \& Leonard JB (1977) Ultrastructure of rumen holotrichs by electron microscopy. J Dairy Sci 60 , 911-918. 
22. Huws SA, Kim EJ, Kingston-Smith AH, et al. (2009) Rumen protozoa are rich in polyunsaturated fatty acids due to the ingestion of chloroplast. FEMS Microbiol Ecol 69, 461-471.

23. Siebertz HP, Heinz E, Linscheid M, et al. (1979) Characterization of lipids from chloroplast envelopes. Eur J Biochem 101, 429-438.

24. Sandelius AS \& Aronsson H (2009) The Chloroplast: Interactions with the Environment, vol. 43. Berlin: Springer Verlag.

25. Faichney GJ (1975) The use of markers to partition digestion within the gastro-intestinal tract of ruminants. In Digestion and Metabolism in the Ruminant, pp. 277-291 [IW McDonald and ACI Warner, editors]. Armidale, NSW: University of New England Publishing Unit.

26. Turner LB, Cairns AJ, Armstead IP, et al. (2005) Dissecting the regulation of fructan metabolism in perennial ryegrass (Lolium perenne) with quantitative trait locus mapping. New Phytol 169, 45-58.

27. Thomas TA (1977) An automated procedure for the determination of soluble carbohydrates in herbage. J Sci Food Agric 28, 639-642.

28. Van Soest PJ, Robertson JB \& Lewis BA (1991) Methods for dietary fiber, neutral detergent fiber and non starch polysaccharides in relation to animal nutrition. J Dairy Sci $\mathbf{7 4}$, 3583-3597.

29. Van Soest PJ \& Wine RH (1967) Use of detergents in the analysis of fibrous feeds. IV. Determination of plant and cell wall constituents. J Assoc Off Anal Chem 50, 50-55.

30. Sukhija PS \& Palmquist DL (1988) Rapid method for determination of total fatty acid content and composition of feedstuffs and feces. J Agric Food Chem 36, 1202-1206.

31. Lee MRF, Harris LJ, Moorby JM, et al. (2002) Rumen metabolism and nitrogen flow to the small intestine in steers offered Lolium perenne containing different levels of water-soluble carbohydrate. Anim Sci 74, 587-596.

32. Arnon DL (1949) Copper enzymes in isolated chloroplasts. Polyphenol oxidase in Beta vulgaris. Plant Physiol 24, 1-15.

33. Edwards JE, Huws SA, Kim EJ, et al. (2007) Characterisation of the dynamics of initial bacterial colonisation of nonconserved forage in the bovine rumen. FEMS Microbiol Ecol 63, 141-141.

34. Edwards JE, Huws SA, Kim EJ, et al. (2007) Corrigendum: characterisation of the dynamics of initial bacterial colonisation of non-conserved forage in the bovine rumen. FEMS Microbiol Ecol 62, 323-335.

35. Skillman LC, Toovey AF, Williams AJ, et al. (2006) Development and validation of a real-time PCR method to quantify rumen protozoa and examination of variability between Entodinium populations in sheep offered a hay-based diet. Appl Environ Microbiol 72, 200-206.

36. Sylvester JT, Karnati SKR, Yu Z, et al. (2004) Development of an assay to quantify rumen ciliate protozoal biomass in cows using real-time PCR. J Nutr 134, 3378-3384.
37. Sylvester JT, Karnati SK, Yu Z, et al. (2005) Evaluation of a real time PCR assay quantifying the ruminal pool size and duodenal flow of nitrogen. J Dairy Sci 88, 2083-2095.

38. Yáñez-Ruiz DR, Scollan ND, Merry RJ, et al. (2006) Contribution of rumen protozoa to duodenal flow of nitrogen, conjugated linoleic acid and vaccenic acid in steers fed silages differing in their water-soluble carbohydrate content. Br J Nutr 96, 861-869.

39. Payne RW, Murray DA, Harding SA, et al. (2010) Genstat ${ }^{\circledR}$ for Windows $^{\mathrm{TM}}$ 13th Edition, Introduction. Hemel Hempstead: VSN International.

40. Kingston-Smith AH \& Theodorou MK (2000) Post-ingestion metabolism of fresh forage. New Phytol 148, 37-55.

41. Volden HLT, Mydland T \& Harstad OM (1999) Chemical composition of protozoal and bacterial fractions isolated from the ruminal contents of dairy cows fed diets differing in nitrogen supplementation. Acta Agric Scand A Anim Sci 49, 235-244.

42. Merry RJ \& McAllan AB (1983) A comparison of the chemical composition of mixed bacteria harvested from the liquid and solid fractions of rumen digesta. Br J Nutr $\mathbf{5 0}$, 701-709.

43. Martin C, Williams AG \& Michalet-Doreau B (1994) Isolation and characteristics of the protozoal and bacterial fractions from bovine and ruminal contents. J Anim Sci 72, 2962-2968.

44. Punia BS, Leibholz J \& Faichney GJ (1992) Rate of production of protozoa in the rumen and the flow of protozoal nitrogen to the duodenum in sheep and cattle given a pelleted diet of lucerne hay and barley. J Agric Sci (Camb) 118, 229-236.

45. Cockburn JE \& Williams AP (1984) The simultaneous estimation of the amounts of protozoal, bacteria and dietary nitrogen entering the duodenum of steers. Br J Nutr $\mathbf{5 1}$, $111-132$.

46. Coleman GS (1979) The role of rumen protozoa in the metabolism of ruminants given tropical feed. Trop Anim Prod 4, 199-213.

47. Harrison DG, Beever DE \& Osbourn DF (1979) The contribution of protozoa to the protein entering the duodenum of sheep. Br J Nutr $\mathbf{4 1}, 521-527$.

48. Belanche A, Abecia L, Holtrop G, et al. (2011) Study of the effect of presence or absence of protozoa on rumen fermentation and microbial protein contribution to the chyme. J Anim Sci 89, 4163-4174.

49. Griinari JM, Corl BA, Lacy SH, et al. (2000) Conjugated linoleic acid is synthesized endogenously in lactating dairy cows by delta(9)-desaturase. J Nutr 130, 2285-2291.

50. Orpin CG \& Letcher AJ (1978) Some factors controlling the attachment of the rumen holotrich protozoa Isotrichia intestinalis and I. prostoma to plant particles in vitro. J Gen Microbiol 106, 33-40. 